\title{
SUSTAINABILITY OF CURRENT ACCOUNT SURPLUSES: EVIDENCE FROM EUROPEAN COUNTRIES
}

Ayşen Sivrikayaa, Zühal Kurula

\begin{abstract}
Over the last two decades, the current accounts in the European Union (EU) have diverged substantially. This divergence has raised concerns about the sustainability of the core countries' current account surpluses since the peripheral countries' financing of their significantly rising levels of current deficits depends on them. In this study, by applying both linear and nonlinear unit root tests and taking into account structural breaks in the data-generating process, we examine the current account sustainability of the main core countries with large external surpluses. We find that the current accounts of Austria, Denmark and Germany are not on sustainable paths, which suggests that the core economies might not continue to run surpluses to finance the peripheral countries' external deficits. The results of this study imply that the policymakers in peripheral countries might take proactive measures against possible borrowing problems and capital outflow risk in the future.
\end{abstract}

Keywords: European imbalances, current account sustainability, nonlinear unit root tests JEL Classification: F32, F10, C51

\section{Introduction}

The current accounts in the European Union (EU) have considerably diverged in last two decades. The core economies such as Austria, Denmark, Finland, Germany, the Netherlands and Sweden have continually had large and persistent capital account surpluses

a Hacettepe University, Ankara, Turkey aysens@hacettepe.edu.tr,zkurul@hacettepe.edu.tr 
while Greece, Portugal, Spain and Ireland have had large deficits. ${ }^{1}$ Although this divergent evolution in external balances has raised concerns, little attention has been paid to the sustainability of the current accounts in the EU. The main reason for not regarding the sustainability of the current accounts as a problem is that the EU had a relatively balanced current account over the period between 1995 and 2011.

Many economists also argue that the current account deficits are the natural by-products of the economic and financial integration of the peripheral countries (e.g., Schmitz and von Hagen, 2011; Campa and Gavilan, 2011). The current account deficits are explained by the large-scale capital inflows into them. The abundance in the liquidity decreases the borrowing costs and expands the domestic demand. This boom spills over into imports, and thus increases current account deficits. Meanwhile, the core economies have continued to have current account surpluses, which cause a divergence in the external balances in the EU. Sinn and Koll (2000) and Blanchard and Giavazzi (2002) state that this divergence is a natural phenomenon since the euro area forms a convergence club, where the poorer individual member states are catching up with their richer counterparts, and naturally run current account deficits during this process.

Although the increase in the current account deficits in the peripheral countries in the EU is an expected consequence of the economic and the financial integration of the markets, it brings about several problems. First of all, the optimistic expectations on convergence and surge in the capital flows deteriorate the tradable sectors by increasing their prices and wages. Secondly, although it highlights the growth potential of the countries with external deficits and helps these countries benefit from the channels of foreign debt, the greater optimism about future growth also leads to lower savings and investment in productive capital (Blanchard and Giavazzi, 2002; Lane and Pels, 2012). Thus, they build up an excessive foreign debt with a low debt servicing capacity. In case of the lack of appropriate financial regulation and low domestic income growth, the increase in the current account deficits in the peripheral countries might reinforce imbalances (Semmler and Tahri, 2017).

1 A core-periphery pattern is first identified in the seminal paper by Bayoumi and Eichengreen (1993), in the run-up to the formation of the EMU. By estimating the degree of supply shock synchronization, they argue that there is a core (Germany, France, Belgium, the Netherlands and Denmark), where supply-side shocks are highly correlated, and a periphery (Greece, Ireland, Italy, Portugal, Spain and the UK), where synchronization is significantly lower. Following this, numerous studies that have recently examined the European external imbalances refer to the greater dispersion in current account balances where relatively rich countries within the EU, such as Germany, have been experiencing large and increasing external surpluses while relatively poorer countries (such as Spain, Greece or Portugal) have been experiencing large and increasing external deficits (Campa and Gavilan, 2011). In this study, we refer to core and peripheral countries as the countries with persistent current account surpluses and with deficits, respectively. 
The continuing current account balance dispersion across countries may also contain serious threats to the European current account adjustments in the future. ${ }^{2}$ This is because a correction to imbalances has undesirable consequences especially for countries with current account deficits. In particular, it can lead to sudden stops in capital flows into these countries and to a decrease in yields on assets. Thereby, the potential reordering might cause a collapse in both external deficits and surpluses, a severe macroeconomic and financial instability over the years and an overall drop of economic growth in Europe. Although current account deficits and surpluses are parts of the macroeconomic adjustment in the EU, external imbalances might be problematic if they become entrenched, as a result of either structural shifts in the economy or mispricing of the risks and overestimation of the expected returns (European Commission, 2012).

The current account dispersion among countries is generated not only by the deficit countries but also by the surplus countries. The leading surplus country is Germany, whose net capital outflows are accepted to be structural (Den Haan et al., 2016). This structure results from both the high level of economic development and aging population. While the high level of economic development shows the strong export competitiveness of the German economy, the aging population causes an increase in the amount of savings. Micossi et al., (2018) specify that the evolution of real exchange rate, the underlying trends in productivity and unit labour costs and the persistent shortfall of investment relative to domestic savings are the main features of German external surplus. However, several scenarios might occur which lead to capital flow reversals. They include a downward trend in economic growth rate, weakening investment, insufficient aggregate demand caused by increasing savings and negative supply shocks. If these scenarios were realized, the problem would not be only Germany's own but would also be a problem for the EU. The reason is that the peripheral countries' current account deficits can be pursued without causing severe problems only if they are financed by countries with surpluses such as Germany. Therefore, for the literature on European imbalances, it is a crucial question whether the core economies can continue to have current account surpluses to offset these deficits. In this study, we aim to address this issue by investigating the sustainability of the core economies' current account data.

Current account sustainability refers to whether an economy is able to meet its intertemporal budget constraint in the long run irrespective of drastic changes in private sector behaviour or in policies (Chen, 2014). Following Trehan and Walsh (1991), who point out that the stationarity of the current account is a sufficient condition

2 Dooley et al. (2004) and Roubini and Setser (2005) point out similar threats in the case of the global imbalances. 
for the intertemporal budget constraint to hold, numerous studies have explored time series behaviours of current account balances. For example, Karunaratne (2010), Holmes et al. (2010), Liu and Tanner (2011), Nag and Mukherjee (2012) examine the mean reverting behaviour of current accounts and investigate whether current account balances are sustainable in the long run using linear panel unit root or cointegration tests.

The aforementioned studies do not take into account the presence of nonlinearity in current account adjustments. However, there are several factors that can alter the time series behaviour of current account balance, such as changes in market participants' risk perceptions, in portfolio allocation decisions and policy changes on international financial markets (Christopoulos and Leon-Ledesma, 2010; Cecen and Xiao, 2014). In this regard, Chen et al. (2013) point out that changes in trade and financial linkages between countries and the rest of world can also cause changes in behaviour of current account balances.

To the best of our knowledge, there are only a few studies that have taken into consideration the presence of nonlinearity in the current account adjustments in the EU. Chen (2014) and Chen and Xie (2015) examine the current account series of only Belgium, the Czech Republic, Finland, Norway, Greece, Ireland, Portugal and Spain. While Chen (2014) does not provide evidence of any asymmetry in the response of current account imbalance to deviations from its long-run trend, Chen and Xie (2015) show that current account sustainability has increased after considering both the size of nonlinearity and structural breaks.

The main contribution of this study to the existing literature is application of nonlinear unit root tests to current account balance series of the countries with surpluses in the EU. Following the related empirical literature, we first apply standard linear unit root tests. After that, we take into consideration the possibility of nonlinearity in the data-generating process by allowing the dynamics to be different over time. In order to capture the presence of nonlinearity in the series, we apply the LM-type linearity tests put forward by Teräsvirta (1994). We then employ the nonlinear unit root tests developed by Kapetanios et al. (2003) to investigate the sustainability of current account imbalances. Finally, we utilize Sollis's (2004) unit root test to check whether our results are robust under different nonlinear modelling approaches.

The rest of the paper is organized as follows. Section 2 presents trends in EU current account balances. Section 3 provides a theoretical framework for the study. Section 4 presents the methodology and reports the data. The empirical results are analysed in Section 5 and finally Section 6 concludes. 


\section{Trends in EU Current Account Balances}

Current account imbalances are one of the distinct features in the EU. As argued by Stockhammer et al. (2016), current accounts of most European countries were close to balance in 1999. However, when the EMU was accomplished, current account positions of member countries diverged substantially. Some of the EU members, headed by Germany, accumulated large and persistent current account surpluses, while others recorded high and persistent deficits. Germany joined the EMU in 1999 with a current account balance of $-1.4 \%$, and reached its peak of $8.5 \%$ in 2016. Although this movement was not continuous, it had a clear upward trend that was unprecedented in German history (Priewe, 2018).

In the period between 2000 and 2011, the core countries ran large surpluses as much as the peripheral countries ran deficits. Although there has been an adjustment and an improvement in the peripheral countries' external imbalances since the 2011 Sovereign Debt Crisis, the EU external balance has disguised considerable imbalances among member countries. Figure 1 shows that Greece, Ireland, Italy, Portugal and Spain have run large current account deficits and these deficits have been rising since the introduction of the euro. As seen in Figure 1, in 19992002, there was a dramatic deterioration of the current account balances in the peripheral countries with their external deficit. Especially, three countries at the heart of the Sovereign Debt Crisis, namely Greece, Spain and Portugal, ran deficits that were increasing significantly over 2003-2011. From 2003 to 2011, the current account deficits in Greece, Portugal, Spain and Ireland averaged over 7\% of their GDPs. After the debt crisis in 2011, the dispersion of the current account balances substantially narrowed. This convergence might have resulted from the fall in domestic demand with a remarkable contraction of the deficits rather than a catching-up effect. However, the current account deficit of these countries increased to $8 \%$ on a 3-year average between 2010 and 2012. As reported in Figure 1, in 2012-2017, the current account balances improved at the periphery and even figured out as surpluses for Spain, Portugal and Italy while Greece and Ireland continued to run deficits.

The deficits in the peripheral countries were largely offset by mainly German current account surpluses and some other core countries such as the Netherlands, Denmark, Sweden and Finland.

Figure 2 reports the current account balances of the countries that finance the external deficits of peripheral countries. As is seen from Figure 2, from 2002 to 2007, Germany ran average surpluses of over 5\% of its GDP. Also, between 2010 and 2012 Germany's surplus on a 3-year average increased to $6.2 \%$ and more recently, in 2016 Germany's surplus reached its peak of $8.5 \%$ of GDP and in 2017 decreased to $7.9 \%$, still remaining at historically high levels. Similar to Germany, the Netherlands ran surpluses on average $7.8 \%$ of its GDP over the years 2004-2017. 
Figure 1: Current account balances in peripheral EU countries

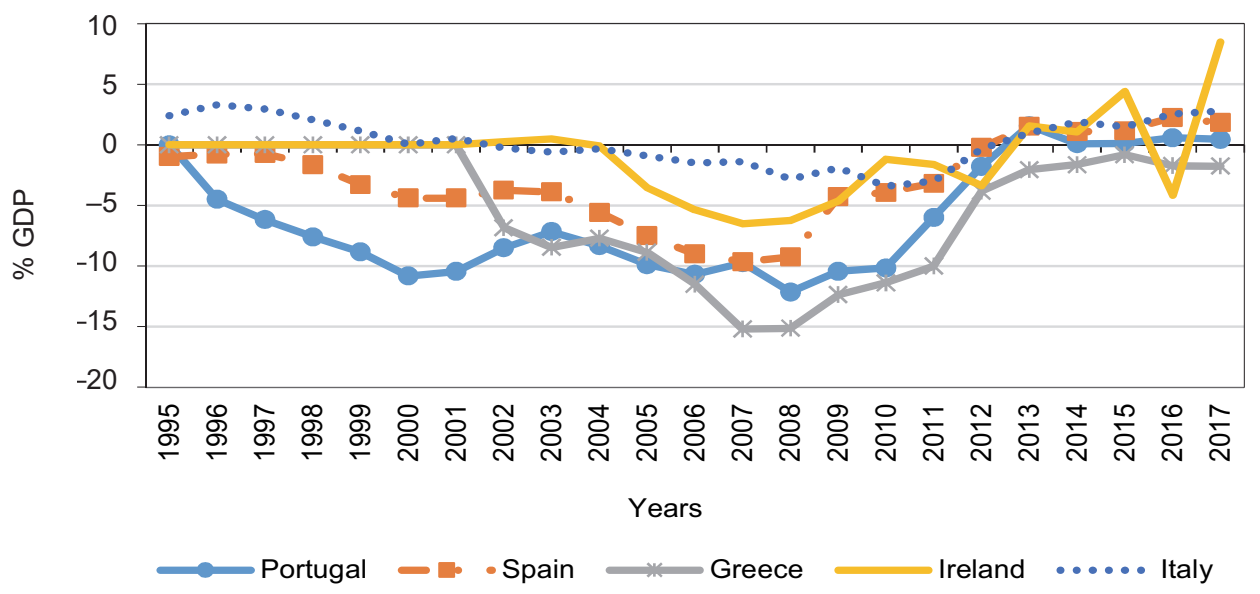

Source: OECD (2018) Main Economic Indicators Balance of payments BPM6

Figure 2: Current account balances of core EU countries

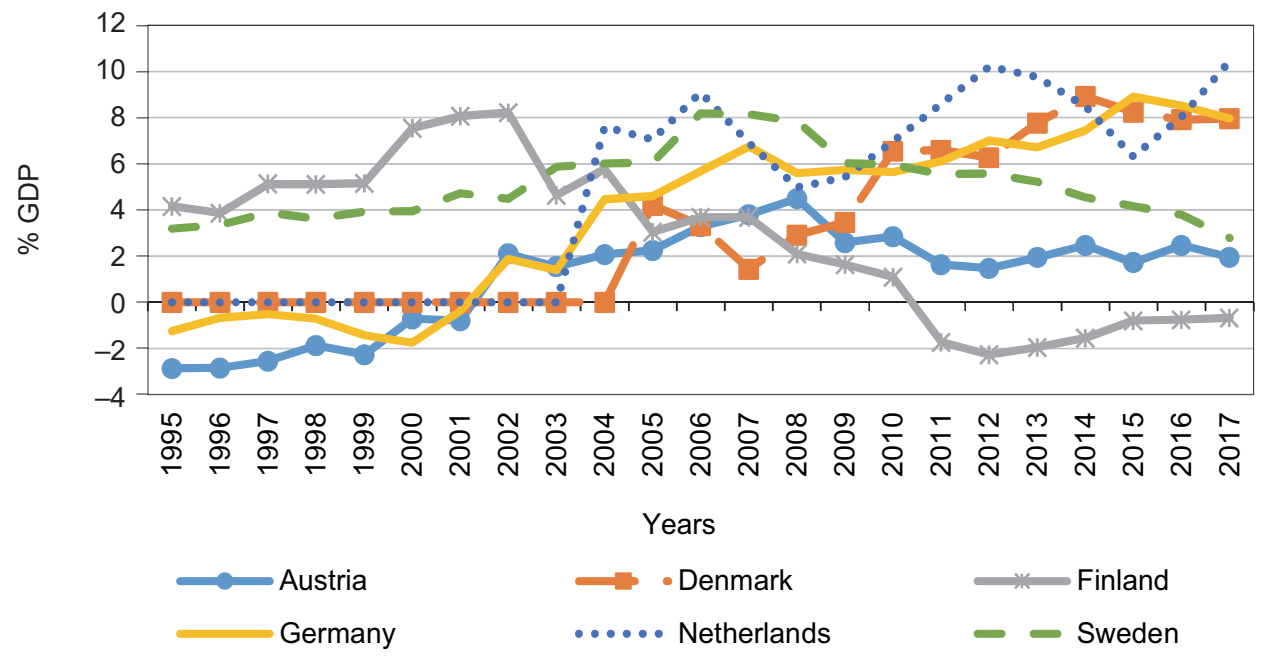

Source: OECD (2018) Main Economic Indicators Balance of payments BPM6

Denmark's surplus increased to almost $6 \%$ of its GDP during the years between 2005 and 2017. For Finland and Sweden, the current account surpluses have been at high levels, such as $4-5 \%$ since the late 1990s. However, Finland's surpluses narrowed after 
the 2008 crisis and then turned into deficits in 2011. In brief, mainly Germany and subsequently the Netherlands, Denmark and Sweden largely offset the deteriorating deficits in the peripheral countries.

There might be two main reasons for these diverging patterns in current account balances. As the first reason, the divergent pattern can be a natural result of higher financial and economic integration on international markets, especially with the creation of the EMU. As pointed out by Blanchard and Giavazzi (2002), higher financial and economic integration reduces the costs and risks of borrowing and lending internationally. Moreover, the investors have ignored the country-specific bankruptcy risk since the introduction of the euro, which eliminated the exchange rate risk (Sinn, 2010; Bertola et al., 2013). In this regard, the literature suggests that the alleviation of transaction costs on international financial operations and elimination of exchange rate risk result in net capital inflows from richer economies to poor countries. The latter will eventually have higher current account deficits (Semmler and Tahri, 2017). Therefore, a higher degree of integration is expected to lead to more dispersion in current account balances across countries.

The second reason of the diverging patterns in current account balances is an excess optimism over a rapid convergence of peripheral countries to the core countries. The excess optimism over the convergence highlights the growth potential of the countries with external deficits and helps these countries benefit from the channels of foreign debt and European financial integration. In the catching-up process, peripheral countries run current account deficits as their imports expand together with incomes. At the same time, inflation undermines their export competitiveness. Consequently, these two interrelated reasons lead to an increase in investment and credit booms in the peripheral countries and considerably high international capital flows from core to periphery. This process results in widening imbalances in current accounts (Bertola et al., 2013).

\section{Current Account Sustainability: Theoretical Considerations}

Current account sustainability implies that an economy is able to meet its intertemporal budget constraint in the long run without any severe change in behaviour of economic agents or in economic policies (Trehan and Walsh, 1991). Hakkio and Rush (1991) and Trehan and Walsh (1991) propose the following budget constraint that a representative small open economy faces:

$$
C_{t}+I_{t}+G_{t}+B_{t}=Y_{t}+\left(1+r_{t}\right) B_{t-1},
$$

where $C_{t}, I_{t}, G_{t}, B_{t}, Y_{t}$ and $r$ represent consumption, investment, government consumption, net foreign assets, income and world interest rate, respectively. $B_{t}$ is obtained using 
Equation 1 as in Equation 2, which relates net foreign assets to current account $\left(C A_{t}\right)$.

$$
B_{t}=\left(1+r_{t}\right) B_{t-1}+C A_{t},
$$

By forward iteration of Equation 2 using the information set $\theta_{t-1}$ being available at the time $t-1$, we can restate the intertemporal condition as follows:

$$
B_{t-1}=-\sum_{j=0}^{\infty} E\left(\prod_{i=0}^{j}\left(\frac{1}{1+r_{t+i}}\right) C A_{t+j} \mid \theta_{t-1}\right)+\lim _{j \rightarrow \infty} E\left(\prod_{i=0}^{j}\left(\frac{1}{1+r_{t+i}}\right) B_{t+j} \mid \theta_{t-1}\right) .
$$

In Equation 3, the first term is the present value of current account surpluses while the second term is the current stock of foreign debt. To satisfy the transversality condition, the second term in Equation 3 must be zero as $j$ goes on to infinity:

$$
\lim _{j \rightarrow \infty} E\left(\prod_{i=0}^{j}\left(\frac{1}{1+r_{t+i}}\right) B_{t+j} \mid \theta_{t-1}\right)=0 .
$$

Fulfilling Equation 4 indicates that the current account is sustainable. ${ }^{3}$ If this condition fails to hold, either the trade surpluses must keep paying off the initial foreign debt or interest payments on foreign debt must be borrowed. According to the intertemporal models of current accounts, large current account imbalances should not persist over time. Countries may only deviate from sustainable levels of current account in the short term (Obstfeld and Rogoff, 1996; Edwards, 2007). Equation 4 is also known as the no-Ponzi game condition, which is a necessary and sufficient condition for the intertemporal budget constraint to hold. Thus, according to the intertemporal budget constraint model, a sufficient condition for Equation 4 to hold is that the current account series is stationary.

\section{Methodology and Data}

In this study, we investigate whether the current account series is stationary relying on the intertemporal models of current accounts. In the empirical literature, most researchers use conventional unit-root tests such as Dickey and Fuller (1979) in order to explore its stationarity. Following them, we first apply the Augmented Dickey-Fuller (ADF) test (Dickey and Fuller, 1981; Said and Dickey, 1984). The ADF test uses Equation 5:

$$
\Delta c_{t}=\varphi c_{t-1}+x_{t}^{\prime} \delta+\sum_{i=1}^{p} \beta_{i} \Delta c_{t-i}+\varepsilon_{t},
$$

where $\Delta$ is the difference operator, $x_{t}$ is a vector of exogenous regressors, which includes a constant, or a constant and trend. Here, $c_{t}$ stands for the current account series. $\varphi, \delta$ and $\beta_{i}$

3 For details, see Trehan and Walsh (1991) and Obstfeld and Rogoff (1996). 
are the parameters of the model. $\varepsilon_{t}$ is assumed to be white noise. The null hypothesis of a unit root $\left(H_{0}: \varphi=0\right)$ against the alternative of a stationary process $\left(H_{0}: \varphi<0\right)$ is tested using $t$-ratio for $\varphi$ as $\mathrm{t}=\hat{\varphi} / s$. $e$. $(\hat{\varphi})$, where $\hat{\varphi}$ is the estimated value of $\varphi$ and $s . e .(\hat{\varphi})$ is its standard error.

In the literature, studies conducted using conventional unit root tests have not been able to reach a consensus on stationarity features of current accounts. This might be because the current account balances follow a nonlinear path, which is contrary to the linearity assumption that these studies rely on (Michael et al., 1997; Enders and Granger, 1998; Caner and Hansen, 2001; Ucar and Omay, 2009; Chen, 2014). In that case, conventional unit root tests may become weaker and lead to acceptance of non-stationarity when the series are actually stationary. Thus, nonlinear unit root tests have gained importance after several studies such as Otto (1992), Chortareas et al. (2004), Christopoulos and Leon-Ledesma (2010), Chen (2014), Cecen and Xiao (2014) and Chen and Xie (2015).

By showing that the ADF test loses power when the actual process is nonlinear, Kapetanios et al. (2003) also develop an alternative method. In this framework, they test the null hypothesis of a unit root process against an alternative of a nonlinear exponential smooth transition autoregressive (ESTAR) process, which is globally stationary. Equation 2 shows the process of the unit root proposed by Kapetanios et al. (2003) based on an ESTAR regression:

$$
\Delta c_{t}=\varphi c_{t-1}+\gamma c_{t-1}\left[1-\exp \left(-\theta c_{t-1}^{2}\right)\right]+\sum_{i=1}^{p} \beta_{i} \Delta c_{t-i}+\epsilon_{t} \quad t=1, \ldots, T .
$$

In Equation 6, the exponential transition function, $F(\theta ; t)=1-\exp \left(-\theta c_{t-1}^{2}\right)$ is a continuous function that is symmetrically U-shaped around zero, and bounded from zero and one. $\theta$ is the parameter that measures the speed of transition between two regimes and corresponds to extreme values of the transition function. In particular, Equation 2 indicates the possibility of an asymmetric speed of adjustment towards equilibrium. For instance, further deviations from fundamental equilibrium in a current account lead to a faster speed of mean reversion. Thus, the current account balance might have different processes with respect to the threshold value.

The ESTAR model reflects a system which captures instability within the neighborhood of the attractor but inclines to display a dampened behaviour towards the attractor when it is (sufficiently far) away from it. In the ESTAR model, for the process to be globally stationary, one must have $\gamma<0$ and $\varphi+\gamma<0$, whereas $\varphi \geq 0$ is possible. Under these circumstances, the process might display a unit root for small values of $c_{t-1}^{2}$, but for larger values of $c_{t-1}^{2}$, it has stable dynamics (Kapetanios et al., 2003).

When we impose $\varphi=0$, which implies that $c_{t}$ follows a unit root in the middle regime, the ESTAR model can be written as follows: 


$$
\Delta c_{t}=\gamma c_{t-1}\left[1-\exp \left(-\theta c_{t-1}^{2}\right)\right]+\sum_{i=1}^{p} \beta_{i} \Delta c_{t-i}+\epsilon_{t} .
$$

Equation 7 shows that the null hypothesis of the global stationarity of the process $c_{t}$ depends only on $\theta$. However, the null hypothesis of $H_{0}: \theta=0$ should be tested against the alternative hypothesis of $H_{1}: \theta>0$ because the parameter $\gamma$ is not identified under the null hypothesis. In that case, the null hypothesis cannot be directly tested. In order to overcome this problem, Kapetanios et al. (2003) develop a $t$-type test statistic by replacing the transition function $F(\theta ; t)=1-\exp \left(-\theta c_{t-1}^{2}\right)$ with its first-order Taylor approximation around $\theta=0$. The regression model can then be written as:

$$
\Delta c_{t}=\delta c_{t-1}^{3}+\sum_{i=1}^{p} \beta_{i} \Delta c_{t-i}+e_{t},
$$

where $e_{t}$ includes the original error term $\epsilon_{t}$ and the error term resulting from the Taylor approximation. The null hypothesis of a unit root, which can be stated as $H_{0}: \delta=0$, can be tested using $t$-statistics.

If the actual data-generating process is a linear process with structural breaks, standard unit root tests again fail and lead to erroneous acceptance of the null hypothesis. In order to allow for structural breaks, an alternative method should be implemented. In the literature, there are various structural break tests. For instance, Perron (1989) suggests adding dummy variables for pre-specified break data to the ADF regression, Perron (1997), Perron and Vogelsang (1992) and Zivot and Andrews (1992) propose different procedures to select the break date endogenously. In order to model nonlinearity that stems from structural breaks, Leybourne et al. (1998) assume that instantaneous structural change may not be appropriate for economic time series and propose a new approach that permits the possibility of smooth transition between two different trend paths over time. Sollis (2004) extends the approach of Leybourne et al. (1998) to allow for both gradual structural change and asymmetric adjustment. In this paper, we employ the methodology proposed by Sollis (2004).

The test procedure of Sollis (2004) combines the threshold autoregressive methodology of Enders and Granger (1998) and the smooth transition methodology of Leybourne et al. (1998) for the null hypothesis of a unit root under the alternative hypothesis of a stationary asymmetric adjustment around a smooth transition between linear trends. Thus, the smooth transition regression model of Sollis (2004) can be written as follows:

$$
c_{t}=\alpha_{1}+\beta_{1} t+\alpha_{2} G_{t}(\gamma, \tau)+\beta_{2} t G_{t}(\gamma, \tau)+v_{t}
$$

where $v_{t}$ is a zero-mean $I(0)$ process and $G_{t}(\gamma, \tau)$ is the logistic smooth transition function, $G_{t}(\gamma, \tau)=\left[1+\exp \{-\gamma(t-\tau T\}]^{-1}\right.$ for a sample of size $T$. This transition function is also 
a continuous and bounded function between zero and one. Therefore, it has two regimes associated with the extreme values of the transition function, $G_{t}(\gamma, \tau)=0$ and $G_{t}(\gamma, \tau)=1$, whereas the transition from one regime to the other is gradual. The parameter determines the mid-point of transition with $G_{\tau T}(\gamma, \tau)=0.5$. The parameter $\gamma$ specifies the speed of transition between the regimes. If it is assumed that $v_{t}$ is a zero-mean $I(0)$ process, then Equation 9 implies that the series under investigation, $c_{t}$, is stationary around a mean which changes from an initial value $\alpha_{1}$ to $\alpha_{1}+\alpha_{2}$. The slope also changes from an initial value $\beta_{1}$ to $\beta_{1}+\beta_{2}$ simultaneously and with the same speed of adjustment (Leybourne et al., 1998). The methodology of Leybourne et al. (1998) is a two-step testing strategy. The first step is to estimate Equation 5 using the nonlinear least squares, and the second one is to perform an $\mathrm{ADF}$ test which the $t$-ratio associated with $\alpha$ in the following regression:

$$
\Delta \hat{v}_{t}=\alpha \hat{v}_{t-1}+\sum_{i=1}^{p} \beta_{i} \Delta \hat{v}_{t-1}+\eta_{t}
$$

However, the procedure of Leybourne et al. (1998) ignores the possibility of the asymmetric speed of adjustment towards equilibrium. In order to take into account the possibility of smooth breaks and asymmetric speed of adjustment toward equilibrium simultaneously, Sollis (2004) assumes that the adjustment speed is nonlinear and $v_{t}$ is generated by the following TAR model:

$$
\Delta \hat{v}_{t}=I_{t} \alpha_{1} \hat{v}_{t-1}+\left(1-I_{t-1}\right) \alpha_{2} \hat{v}_{t-1}+\sum_{i=1}^{p} \beta_{i} \Delta \hat{v}_{t-1}+\eta^{\prime}{ }_{t},
$$

where $I_{t}=1$ if $\hat{v}_{t-1} \geq 0, I_{t}=0$ if $\hat{v}_{t-1}<0$, and $\eta_{t}$ is a zero-mean stationary process. Thus $c_{t}$ is a smooth transition TAR (ST-TAR) process. If $\alpha_{1}=\alpha_{2}=0$ in Equation 11, then $\hat{v}_{t-}$ and therefore $c_{t}$, contains a unit root, whereas if $\alpha_{1}=\alpha_{2}<0, c_{t}$, is a stationary ST-TAR process with symmetric adjustment. If $\alpha_{1}<0, \alpha_{2}<0$, and $\alpha_{1} \neq \alpha_{2}$, then $c_{t}$, is a stationary ST-TAR process with asymmetric adjustment. Sollis (2004) suggests testing the null hypothesis of a unit root by using either the $F$ - statistics for testing $\alpha_{1}=\alpha_{2}=0$ in Equation 11 or the most significant of the $t$-statistics from those testing $\alpha_{1}=0$ and $\alpha_{2}=0$.

In this study, we use a quarterly seasonally adjusted current account balance to GDP ratio. We have different time spans for the countries in our sample. We analyse the time series properties of current account balances over the periods 1996:1-2018:3 for Austria, 2005:Q1-2018:Q3 for Denmark; 1991:Q1-2018:Q3 for Germany; 1995:Q1-2018:Q3 for Finland; 2003:Q1-2018:Q3 for the Netherlands, and1993:Q1-2018:Q3 for Sweden. ${ }^{4}$ All the data are obtained from the OECD database.

4 The selection of the countries is based on the European core-periphery perspective of Bayoumi and Eichengreen (1993). 


\section{Empirical Results}

We consider two groups of tests in order to analyse the order of integration of the ratio of current account balance to GDP for the individual countries. One group is linear unit root tests, which consists of the Augmented Dickey-Fuller (ADF) test and the KPSS test proposed by Kwiatkowski et al. (1992). The other group includes the nonlinear unit root tests which are proposed by Kapetanios et al. (2003) (hereafter KSS) and Sollis (2004).

The results of the ADF tests in Table 1 indicate that the null hypothesis of a unit root cannot be rejected for all the current account series of the countries under investigation except the one for the Netherlands, which is trend-stationary. The results of the KPSS tests confirm the results of the ADF tests.

Table 1: Results of linear unit root tests

\begin{tabular}{l|c|c|c|c}
\hline \multirow{2}{*}{ Level } & \multicolumn{2}{|c|}{ ADF } & \multicolumn{2}{c}{ KPSS } \\
\hline Austria & Constant & $\begin{array}{c}\text { Constant } \\
\text { and trend }\end{array}$ & $\begin{array}{c}\text { Constant } \\
\text { and trend }\end{array}$ \\
\hline Denmark & -2.130 & -2.283 & $0.737^{* *}$ & $0.305^{* * *}$ \\
\hline Finland & -1.863 & -2.833 & $0.645^{* *}$ & $0.136^{*}$ \\
\hline Germany & -0.053 & -2.735 & $1.020^{* * *}$ & $0.169^{* *}$ \\
\hline Netherlands & -1.303 & -3.102 & $1.128^{* * *}$ & $0.123^{*}$ \\
\hline Sweden & -2.365 & $-7.914^{* * *}$ & $0.396^{*}$ & 0.062 \\
\hline
\end{tabular}

\section{Difference}

\begin{tabular}{l|c|c|c|c}
\hline Austria & $-7.910^{* * *}$ & $-8.087^{* * *}$ & 0.199 & 0.104 \\
\hline Denmark & $-9.238^{* * *}$ & $-9.143^{* * *}$ & 0.047 & 0.046 \\
\hline Finland & $-14.591^{* * *}$ & $-14.545^{* * *}$ & 0.130 & 0.079 \\
\hline Germany & $-12.822^{* * *}$ & $-12.765^{* * *}$ & 0.114 & 0.102 \\
\hline Netherlands & $-10.524^{* *}$ & $-10.433^{* * *}$ & 0.220 & $0.217^{* * *}$ \\
\hline Sweden & $-11.184^{* * *}$ & $-12.104^{* * *}$ & $0.582^{* *}$ & 0.069 \\
\hline
\end{tabular}

Notes:

(i) The null hypothesis of the ADF test is that the series has a unit root, while the null hypothesis of the KPSS test is that the series is stationarity.

(ii) $\quad{ }^{*},{ }^{*}$ and ${ }^{* *}$ denotes $10 \%, 5 \%$ and $1 \%$ significance level, respectively.

Source: Authors. 
Either the non-rejection of the null hypothesis of a unit root by the ADF or the rejection of the null hypothesis of stationarity by the KPSS tests do not necessarily mean that the series is not stationary because these tests do not consider the presence of nonlinear adjustments and structural breaks. The nonlinearity of the current account series may stem from changes in investors' risk perceptions, portfolio allocation decisions, future policy changes and transaction costs in international financial flows (Chortareas et al., 2004; Christopoulos and Leon-Ledesma, 2010; Cecen and Xiao, 2014). To address these issues, we analyse whether the individual countries' current account balance series exhibits nonlinearity using LM-type linearity tests proposed by Teräsvirta (1994).

LM-type linearity tests have a three-step procedure. ${ }^{5}$ The first step is to specify an appropriate linear model of current account series. In the second step, we use the model as the benchmark model to construct a nonlinear model based on a smooth transition autoregressive model. We then obtain the auxiliary regression model by replacing the transition function of the STAR model with its first-order Taylor approximation. In the third step, the null hypothesis of linearity is tested against the alternative of STAR-type nonlinearity. In order to test for the null hypothesis, several lagged current account series and time trend are used as candidate transition variables.

The results of the LM-type linearity tests are reported in Table 2. As can be seen from Table 2, the null hypothesis of linearity cannot be rejected at the $5 \%$ significance level in any model using any candidate transition variable for the cases of Austria and Denmark. For the cases of Finland, Germany, the Netherlands and Sweden for at least one candidate transition variable, linearity of the models is rejected. Thus, we find that current account balances of Finland, Germany, the Netherlands and Sweden have nonlinear datagenerating processes. Since only these four countries' current account balance series exhibit nonlinearity, we pursue the analysis by applying the nonlinear unit root tests to them.

In order to explore a unit root in the current account series using nonlinear modelling approach, we first employ KSS nonlinear unit root tests for raw data, for demeaned data and for demeaned and detrended data, respectively. The results, demonstrated in Table 3, suggest that the null hypothesis of a unit root cannot be rejected for Germany and the Netherlands even at the $10 \%$ significance level. Only the current account series of Finland and Sweden exhibit nonlinear stationary process.

5 See Teräsvirta (1994), Teräsvirta and Anderson (1992) and van Dijk (1999) for details on the modelling of the linearity test and its empirical procedure. 
Table 2: Results of linearity tests

\begin{tabular}{|c|c|c|c|c|c|c|}
\hline $\begin{array}{l}\text { Candidate } \\
\text { transition var. }\end{array}$ & Austria & Denmark & Finland & Germany & Netherlands & Sweden \\
\hline Lags (p): & 5 & 2 & 3 & 2 & 2 & 3 \\
\hline$c a_{t-1}$ & $\begin{array}{c}1.295 \\
(0.232)\end{array}$ & $\begin{array}{c}0.541 \\
(0.775)\end{array}$ & $\begin{array}{c}1.478 \\
(0.196)\end{array}$ & $\begin{array}{c}2.027 \\
(0.069)\end{array}$ & $\begin{array}{l}13.580 \\
(0.000)\end{array}$ & $\begin{array}{c}2.726 \\
(0.008)\end{array}$ \\
\hline$c a_{t-2}$ & $\begin{array}{c}1.259 \\
(0.254)\end{array}$ & $\begin{array}{c}0.583 \\
(0.742)\end{array}$ & $\begin{array}{c}1.214 \\
(0.307)\end{array}$ & $\begin{array}{c}2.058 \\
(0.065)\end{array}$ & $\begin{array}{c}9.000 \\
(0.000)\end{array}$ & $\begin{array}{l}3.627 \\
(0.001)\end{array}$ \\
\hline$c a_{t-3}$ & $\begin{array}{c}0.647 \\
(0.825)\end{array}$ & $\begin{array}{c}0.707 \\
(0.699)\end{array}$ & $\begin{array}{c}0.759 \\
(0.655)\end{array}$ & $\begin{array}{c}1.844 \\
(0.070)\end{array}$ & $\begin{array}{l}0.377 \\
(0.001)\end{array}$ & $\begin{array}{c}2.273 \\
(0.024)\end{array}$ \\
\hline$c a_{t-4}$ & $\begin{array}{c}0.555 \\
(0.898)\end{array}$ & $\begin{array}{c}0.311 \\
(0.967)\end{array}$ & $\begin{array}{l}1.078 \\
(0.388)\end{array}$ & $\begin{array}{c}1.484 \\
(1.165)\end{array}$ & $\begin{array}{c}2.042 \\
(0.056)\end{array}$ & $\begin{array}{c}1.912 \\
(0.044)\end{array}$ \\
\hline$c a_{t-5}$ & $\begin{array}{c}0.531 \\
(0.914)\end{array}$ & $\begin{array}{c}0.341 \\
(0.955)\end{array}$ & $\begin{array}{c}1.072 \\
(0.392)\end{array}$ & $\begin{array}{c}1.519 \\
(0.153)\end{array}$ & $\begin{array}{c}1.439 \\
(0.201)\end{array}$ & $\begin{array}{c}3.221 \\
(0.000)\end{array}$ \\
\hline$c a_{t-6}$ & $\begin{array}{l}0.687 \\
(0.810)\end{array}$ & $\begin{array}{c}0.458 \\
(0.893)\end{array}$ & $\begin{array}{c}0.553 \\
(0.831)\end{array}$ & $\begin{array}{c}1.656 \\
(0.111)\end{array}$ & $\begin{array}{c}1.763 \\
(0.103)\end{array}$ & $\begin{array}{c}2.087 \\
(0.027)\end{array}$ \\
\hline$c a_{t-7}$ & $\begin{array}{c}0.393 \\
(0.985)\end{array}$ & $\begin{array}{c}1.237 \\
(0.304)\end{array}$ & $\begin{array}{c}1.598 \\
(0.131)\end{array}$ & $\begin{array}{c}1.831 \\
(0.073)\end{array}$ & $\begin{array}{c}1.914 \\
(0.076)\end{array}$ & $\begin{array}{c}2.366 \\
(0.012)\end{array}$ \\
\hline$c a_{t-8}$ & $\begin{array}{l}1.018 \\
(0.455)\end{array}$ & $\begin{array}{c}0.337 \\
(0.956)\end{array}$ & $\begin{array}{c}0.863 \\
(0.562)\end{array}$ & $\begin{array}{c}1.263 \\
(0.268)\end{array}$ & $\begin{array}{c}2.389 \\
(0.028)\end{array}$ & $\begin{array}{c}1.628 \\
(0.100)\end{array}$ \\
\hline$c a_{t-9}$ & $\begin{array}{c}0.376 \\
(0.988)\end{array}$ & $\begin{array}{c}0.661 \\
(0.738)\end{array}$ & $\begin{array}{c}0.930 \\
(0.505)\end{array}$ & $\begin{array}{c}1.267 \\
(0.267)\end{array}$ & $\begin{array}{l}15.603 \\
(0.000)\end{array}$ & $\begin{array}{c}4.049 \\
(0.000)\end{array}$ \\
\hline$c a_{t-10}$ & $\begin{array}{c}0.711 \\
(0.786)\end{array}$ & $\begin{array}{c}0.726 \\
(0.682)\end{array}$ & $\begin{array}{c}0.997 \\
(0.052)\end{array}$ & $\begin{array}{c}1.339 \\
(0.229)\end{array}$ & $\begin{array}{c}2.760 \\
(0.013)\end{array}$ & $\begin{array}{c}2.615 \\
(0.006)\end{array}$ \\
\hline$c a_{t-11}$ & $\begin{array}{c}0.576 \\
(0.901)\end{array}$ & $\begin{array}{c}0.539 \\
(0.835)\end{array}$ & $\begin{array}{c}1.628 \\
(0.124)\end{array}$ & $\begin{array}{c}1.089 \\
(0.379)\end{array}$ & $\begin{array}{c}5.077 \\
(0.000)\end{array}$ & $\begin{array}{c}1.873 \\
(0.051)\end{array}$ \\
\hline$c a_{t-12}$ & $\begin{array}{c}0.850 \\
(0.636)\end{array}$ & $\begin{array}{c}0.272 \\
(1.291)\end{array}$ & $\begin{array}{c}1.957 \\
(0.058)\end{array}$ & $\begin{array}{c}1.014 \\
(0.435)\end{array}$ & $\begin{array}{c}2.565 \\
(0.026)\end{array}$ & $\begin{array}{l}2.8823 \\
(0.003)\end{array}$ \\
\hline Trend & $\begin{array}{c}0.850 \\
(0.636)\end{array}$ & $\begin{array}{l}(1.893) \\
(0.081)\end{array}$ & $\begin{array}{c}2.619 \\
(0.010)\end{array}$ & $\begin{array}{c}2.665 \\
(0.008)\end{array}$ & $\begin{array}{c}1.173 \\
(0.335)\end{array}$ & $\begin{array}{c}3.476 \\
(0.000)\end{array}$ \\
\hline
\end{tabular}

Notes:

(i) The null hypothesis of the linearity test is that the auxiliary regression model is linear.

(ii) The figures in the parentheses are $p$-values of the related statistics.

Source: Authors. 
Table 3: Results of KSS nonlinear unit root test

\begin{tabular}{l|c|c|c}
\hline $\boldsymbol{t}_{N L}$ & Case 1 & Case 2 & Case 3 \\
\hline Finland & $-1.344(2)$ & $-2.076(1)$ & $-3.468(1)$ \\
\hline Germany & $-0.774(1)$ & $-2.023(1)$ & $-1.744(1)$ \\
\hline Netherlands & $-2.305(2)$ & $-0.459(2)$ & $-0.082(2)$ \\
\hline Sweden & $-1.269(2)$ & $-3.044(2)$ & $-1.799(2)$ \\
\hline Significance level & \multicolumn{3}{|c}{ Asymptotic critical values } \\
\hline $\mathbf{1 \%}$ & -2.82 & -3.48 & -3.93 \\
\hline $\mathbf{5 \%}$ & -2.22 & -2.93 & -3.40 \\
\hline $\mathbf{1 0} \%$ & -1.92 & -2.66 & -3.13 \\
\hline
\end{tabular}

Notes:

(i) The null hypothesis of the KSS nonlinear unit root test is that the series has a unit root, which can be stated as $H_{0}: \delta=0$ in the model given in Equation 8.

(ii) Case 2 is used for the case with nonzero mean and Case 3 is used for the case with nonzero mean and nonzero linear trend.

(iii) Figures in parentheses are the numbers of optimal lag lengths for the models used. Optimal lag lengths are selected so as to remove any significant autocorrelation in residuals.

(iv) Asymptotic critical values for the KSS nonlinear unit root test statistics are taken from Table 1 in Kapetanios et al. (2003, p. 364).

Source: Authors.

Most of the recent studies on current account balances have focused on nonlinear adjustment of the data without taking account of the possibility of structural changes. However, Perron (1989, 1990), Perron and Vogelsang (1992) and Zivot and Andrews (1992) have argued that structural breaks in the mean-reverting process may render the results of unit root tests misleading. In this study, we apply the nonlinear unit root test developed by Sollis (2004), a modelling approach allowing for structural breaks in the data-generating process.

Table 4 reports the results of the nonlinear unit root tests of Sollis (2004), which reveal that the null hypothesis of a unit root can be rejected at the $5 \%$ level of significance for the case with a break in the intercept for Finland and Sweden. For the Netherlands, the null hypothesis of a unit root can be rejected when the model has a break in the trend as well as a break in the intercept. The result related to the Netherlands is in line with the ADF and KPSS test results. The current account series for Germany has a unit root. These results indicate the robustness of our empirical findings to different specifications. 


\begin{tabular}{l|c|c|c|c}
\hline \multirow{2}{*}{ Finland } & \multicolumn{2}{|c|}{ Break in intercept only } & \multicolumn{2}{c}{ Break in intercept and trend } \\
\cline { 2 - 5 } & F-statistics & t-statistics & F-statistics & t-statistics \\
\hline Germany & $\mathbf{1 0 . 4 8 1}$ & -2.839 & 3.802 & -1.465 \\
\hline Netherlands & 6.680 & -1.958 & 3.310 & -2.018 \\
\hline Sweden & $\mathbf{1 0 . 5 3 1}$ & -1.696 & 10.396 & -1.731 \\
\hline Significance level & $\mathbf{1 0 . 2 0 9}$ & -2.891 & 10.582 & -3.233 \\
\hline $\mathbf{1 \%}$ & 12.244 & -3.994 & 16.834 & -4.586 \\
\hline $\mathbf{5 \%}$ & 9.191 & -3.417 & 13.408 & -4.049 \\
\hline $\mathbf{1 0 \%}$ & 7.844 & -3.169 & 11.862 & -3.803 \\
\hline
\end{tabular}

Notes:

(i) The null hypothesis of the ST-TAR unit root test is that the series has a unit root, which can be stated as $H_{0}: \alpha_{1}=\alpha_{2}=0$ or $H_{0}: \alpha_{1}=0$ or $H_{0}: \alpha_{2}=0$ in the model given in Equation 11 .

(ii) Optimal lag lengths removing any significant autocorrelation in residuals are 1 for all models.

(iii) The simulated critical values for the ST-TAR unit root test statistics are taken from Table 1 in Sollis (2004, p. 413).

Source: Authors.

\section{Conclusion}

This paper aims to examine the current account sustainability of the European countries, such as Austria, Denmark, Finland, Germany, the Netherlands and Sweden, that run current account surpluses in order to contribute to the recent discussions of European imbalances. To this end, based on the intertemporal models of current accounts, we examine the meanreverting features of the current account balance to GDP ratio for them. We apply both linear and nonlinear unit root tests and take account of structural breaks in the datagenerating process.

The results of the linearity tests show that Finland, Germany, the Netherlands and Sweden exhibit nonlinear dynamics. Since the current account series of Austria and Denmark can be linearly modelled to test for unit root, we get evidence from the results of the ADF and the KPSS tests that they are nonstationary. In the presence of both nonlinearity and structural breaks, we find that the current account balance of Germany is nonstationary using nonlinear unit root tests. That is, our results suggest that the current account balances of Austria, Denmark and Germany are not on sustainable paths. 
The results of this study have three important policy implications. Firstly, this study reveals that Finland, the Netherlands and Sweden might continue to have current account surpluses in the future while Austria, Denmark and Germany might not. Regarding Germany, our study is in line with Anders (2017), who also predicts that wage rises, increased investment and aging populations will be the sources of drops in current account surpluses in Germany in the future years. Besides, Kollmann et al. (2015) illustrate that the drivers of possible decrease in current account surpluses in Germany are expected to be expansionary fiscal policy as well as wage rises. Although the drivers of surpluses for Germany are investigated in several studies, future studies are needed to reveal them for Austria and Denmark.

Secondly, the results of this study implies that some of the core economies of Europe (Austria, Denmark and Germany) might not continue to run surpluses to finance the peripheral external deficits forever. In this case, the peripheral countries will face borrowing problems in the future. Therefore, the policymakers in these countries might take proactive measures beforehand.

Third, if the current account balance dispersion continues across countries, this might contain serious capital outflow risk in peripheral countries. This threat materialized in the 2011 Sovereign Debt Crisis. Because of the sudden stop in capital flows to some peripheral countries such as Portugal and Greece in 2011, they became insolvent, causing macroeconomic and financial instability in these countries. Therefore, it is important for policy makers to care about distortionary correction in the future.

\section{References}

Anders, L. N. (2017). The German Current Account: A Comparison of American and European Perspectives and Policies. Available at: https://repository.upenn.edu/sire/54/

Bayoumi, T., Eichengreen, B. (1993). Shocking Aspects of European Monetary Integration, in Torres, F., Giavazzi, F., eds., Adjustment and Growth in the European Monetary Union. Cambridge: Cambridge University Press, pp 193-235, https://doi.org/10.1017/ cbo9780511599231.014

Bertola, G., Driffill, J., James, H., Sinn, H. W., Sturm, J. E., Valentinyi, Á. (2013). European Imbalances. CESifo. Munich EEAG Report on the European Economy, pp. 55-72. Available at: http://www.cesifo-group.de/DocDL/eeag_report_chap2_2013.pdf

Blanchard, O., Giavazzi, F. (2002). Current Account Deficits in the Euro Area: the End of the Feldstein-Horioka Puzzle? Brookings Papers on Economic Activity, 2, 147-209, https://doi.org/10.1353/eca.2003.0001

Campa, J. M., Gavilan, A. (2011). Current Accounts in the Euro Area: An Intertemporal Approach. Journal of International Money and Finance, 30(1), 205-228, https://doi. org/10.1016/j.jimonfin.2010.08.003 
Caner, M., Hansen, B. E. (2001). Threshold Autoregression with a Unit Root. Econometrica, 69(6), 1555-1596, https://doi.org/10.1111/1468-0262.00257

Cecen, A., Xiao, L. (2014). Capital Flows and Current Account Dynamics in Turkey: A Nonlinear Time Series Analysis. Economic Modelling, 39, 240-246,https://doi.org/10.1016/j. econmod.2014.03.010

Chen, R., Milesi-Ferretti, G. M., Tressel, T. (2013). External Imbalances in the Eurozone. Economic Policy, 28(73), 101-142,https://doi.org/10.1111/1468-0327.12004

Chen, S. W. (2014). Smooth Transition, non-linearity and Current Account Sustainability: Evidence from the European Countries. Economic Modelling, 38, 541-554, https://doi.org/10.1016/j.econmod.2014.02.003

Chen, S. W., Xie, Z. (2015). Testing for Current Account Sustainability under Assumptions of Smooth Break and Nonlinearity. International Review of Economics \& Finance, 38, 142-156, https://doi.org/10.1016/j.iref.2015.02.015

Chortareas, G. E., Kapetanios, G., Uctum, M. (2004). An Investigation of Current Account Solvency in Latin America using Nonlinear Nonstationarity Tests. Studies in Nonlinear Dynamics \& Econometrics, 8(1), https://doi.org/10.2202/1558-3708.1200

Christopoulos, D., León-Ledesma, M. A. (2010). Current Account Sustainability in the US: What did we Really Know about it? Journal of International Money and Finance, 29(3), 442-459,https://doi.org/10.1016/j.jimonfin.2009.06.014

Den Haan, M. E., Ellison, M., Ilzetzki, E., McMahon, M., Reis, R. (2016). The Danger of Germany's Current Account Surpluses: Results of the CFM and CEPR Survey. Vox CEPR's Policy Portal, 27. Available at: https://warwick.ac.uk/fac/soc/economics/research/centres/cage/ manage/publications/74_den_haan_1_17_the_danger_of_germanys.pdf

Dickey, D. A., Fuller, W. A. (1979). Distribution of the Estimators for Autoregressive Time Series with a Unit Root. Journal of the American Statistical Association, 74(366a), 427-431, https://doi.org/10.1080/01621459.1979.10482531

Dickey, D. A., Fuller, W. A. (1981). Likelihood Ratio Statistics for Autoregressive Time Series with a Unit Root. Econometrica: Journal of the Econometric Society, 49(4), 1057-1072, https://doi.org/10.2307/1912517

Dooley, M. P., Folkerts-Landau, D., Garber, P. (2004). The Revived Bretton Woods System: the Effects of Periphery Intervention and Reserve Management on Interest Rates \& Exchange Rates in Center Countries. National Bureau of Economic Research. Cambridge Working Paper No. 10332, https://doi.org/10.3386/w10332

Edwards, S. (2007). On Current Account Surpluses and the Correction of Global Imbalances. National Bureau of Economic Research. Cambridge Working Papers No. 12904, https://doi.org/10.3386/w12904

Enders, W., Granger, C. W. J. (1998). Unit-root Tests and Asymmetric Adjustment with an Example Using the Term Structure of Interest Rates. Journal of Business \& Economic Statistics, 16(3), 304-311, https://doi.org/10.1080/07350015.1998.10524769 
European Commission (2012). Current Account Surpluses in EU. European Union, https://doi. org/10.2765/19685

Gourinchas, P.-O. (2002). Comments on Current Account Deficits in the Euro Area.

The End of the Feldstein-Horioka Puzzle Brookings Papers on Economic Activity, 2, 196-206,https://doi.org/10.1353/eca.2003.0001

Hakkio, C. S., Rush, M. (1991). Is the Budget Deficit "Too Large? Economic Inquiry, 29(3), 429-445,https://doi.org/10.1111/j.1465-7295.1991.tb00837.x

Holmes, M. J. (2006). How Sustainable are OECD Current Account Balances in the Long Run? The Manchester School, 74(5), 626-643, https://doi. org/10.1111/j.1467-9957.2006.00514.x

Holmes, M. J., Otero, J., Panagiotidis, T. (2010). On the Stationarity of Current Account Deficits in the European Union. Review of International Economics, 18(4), 730-740, https://doi. org/10.1111/j.1467-9396.2010.00896.x

Kapetanios, G., Shin, Y., Snell, A. (2003). Testing for a Unit Root in the Nonlinear STAR Framework. Journal of Econometrics, 112(2), 359-379, https://doi.org/10.1016/ S0304-4076(02)00202-6

Karunaratne, N. D. (2010). The Sustainability of Australia's Current Account Deficits-A Reappraisal after the Global Financial Crisis. Journal of Policy Modeling, 32(1), 81-97, https://doi.org/10.1016/j.jpolmod.2009.10.002

Kollmann, R., Ratto, M., Roeger, W., Vogel, L. (2015). What Drives the German Current Account? And How does it Affect other EU Member States? Economic Policy, 30(81), 47-93, https://doi.org/10.1093/epolic/eiu004

Kwiatkowski, D., Phillips, P. C., Schmidt, P., Shin, Y. (1992). Testing the Null Hypothesis of Stationarity Against the Alternative of a Unit Root: How Sure are we that Economic Time Series have a Unit Root? Journal of Econometrics, 54(1-3), 159-178, https://doi. org/10.1016/0304-4076(92)90104-Y

Lane, P. R., Pels, B. (2012). Current Account Imbalances in Europe (May 2012). CEPR. Discussion Paper No. 8958. Available at: https://ideas.repec.org/p/cpr/ceprdp/8958.html

Leybourne, S., Newbold, P., Vougas, D. (1998). Unit Roots and Smooth Transitions. Journal of Time Series Analysis, 19(1), 83-97, https://doi.org/10.1111/1467-9892.00078

Liu, P. C., Tanner, E. (1996). International Intertemporal Solvency in Industrialized Countries: Evidence and Implications. Southern Economic Journal, 62(3), 739-749, https://doi. org/10.2307/1060891

Michael, P., Nobay, A. R., Peel, D. A. (1997). Transactions Costs and Nonlinear Adjustment in Real Exchange Rates; An Empirical Investigation. Journal of Political Economy, 105(4), 862-879, https://doi.org/10.1086/262096

Micossi, S., D'Onofrio, A., Peirce, F. (2018). On German External Imbalances. CEPS Policy Insight. Available at: https://ssrn.com/abstract $=3300630$ 
Nag, B., Mukherjee, J. (2012). The Sustainability of Trade Deficits in the Presence of Endogenous Structural Breaks: Evidence from the Indian Economy. Journal of Asian Economics, 23(5), 519-526, https://doi.org/10.1016/j.asieco.2012.05.003

Obstfeld, M., Rogoff, K. S. (1996). Foundations of International Macroeconomics. Cambridge, MA: MIT press. ISBN 9780262150477.

OECD (2018). OECD Stat, (database). Available at: https://stats.oecd.org/

Perron, P. (1989). The Great Crash, the Oil Price Shock, and the Unit Root Hypothesis. Econometrica: Journal of the Econometric Society, 57(6), 1361-1401, https://doi.org/10.2307/1913712

Perron, P. (1997). Further Evidence on Breaking Trend Functions in Macroeconomic Variables. Journal of Econometrics, 80(2), 355-385,https://doi.org/10.1016/ S0304-4076(97)00049-3

Perron, P., Vogelsang, T. J. (1992). Nonstationarity and Level Shifts with an Application to Purchasing Power Parity. Journal of Business \& Economic Statistics, 10(3), 301-320, https://doi.org/10.1080/07350015.1992.10509907

Priewe, J. (2018). A Time Bomb for the Euro? Understanding Germany's Current Account Surplus. IMK Study No. 59. Available at: https://www.econstor.eu/handle/10419/191722

Roubini, N., Setser, B. (2005). Will the Bretton Woods 2 Regime Unravel Soon? The Risk of a Hard Landing in 2005-2006. Unpublished Manuscript, New York University and Oxford University, 6.

Said, S. E., Dickey, D. A. (1984). Testing for Unit Roots in Autoregressive-moving Average Models of Unknown Order. Biometrika, 71(3), 599-607, https://doi.org/10.1093/ biomet/71.3.599

Schmitz, B., von Hagen, J. (2011). Current Account Imbalances and Financial Integration in the Euro Area. Journal of International Money and Finance, 30(8), 1676-1695, https://doi.org/10.1016/j.jimonfin.2011.08.003

Semmler, W., Tahri, I. (2017). Current Account Imbalances: A New Approach to Assess External Debt Sustainability. Economic Modelling, 62, 161-170, https://doi.org/10.1016/j. econmod.2016.12.005

Sinn, H. W., Koll, R. (2000). The Euro, Interest Rates and European Economic Growth. München: ifo Institut für Wirtschaftsforschung an der Universität München. CESifo Forum 1(3), pp. 30-31). Available at: https://www.econstor.eu/bitstream/10419/166058/1/cesifoforum-v01-y2000-i3-p30-31.pdf

Sollis, R. (2004). Asymmetric Adjustment and Smooth Transitions: a Combination of some Unit Root Tests. Journal of Time Series Analysis, 25(3), 409-417, https://doi.org/10.1111/j.1467-9892.2004.01911.x

Stockhammer, E., Constantine, C., Reissl, S. (2016). Explaining the Euro Crisis: Current Account Imbalances, Credit Booms and Economic Policy in Different Economic Paradigms. Post Keynesian Economics Society (PKES). Working Papers PKWP1617. 
Teräsvirta, T. (1994). Specification, Estimation, and Evaluation of Smooth Transition

Autoregressive Models. Journal of the American Statistical Association, 89(425), 208-218, https://doi.org/10.1080/01621459.1994.10476462

Teräsvirta, T., Anderson, H. M. (1992). Characterizing Nonlinearities in Business Cycles Using Smooth Transition Autoregressive Models. Journal of Applied Econometrics, 7(S1), 119-136, https://doi.org/10.1002/jae.3950070509

Trehan, B., Walsh, C. E. (1991). Testing Intertemporal Budget Constraints: Theory and Applications to US Federal Budget and Current Account Deficits. Journal of Money, Credit and Banking, 23(2), 206-223, https://doi.org/10.2307/1992777

Ucar, N., Omay, T. (2009). Testing for Unit Root in Nonlinear Heterogeneous Panels. Economics Letters, 104(1), 5-8, https://doi.org/10.1016/j.econlet.2009.03.018

van Dijk, D. J. C. (1999). Smooth Transition Models: Extensions and Outlier Robust Inference. Tinbergen Institute Research Series No. 200.

Zivot, E., Andrews, D. W. K. (2002). Further Evidence on the Great Crash, the Oil-price Shock, and the Unit-root Hypothesis. Journal of Business \& Economic Statistics, 20(1), 25-44, https://doi.org/10.1198/073500102753410372 